\title{
Principles of soil development in the Quaternary
}

\author{
Libuše Smolíková \\ Geological Institute, Univerzita Karlova, Prag 2, Czechoslovakia \\ Correspondence: Christine Thiel (christine.thiel@bgr.de) \\ Relevant dates: $\quad$ Published: 17 December 2021
}

How to cite: $\quad$ Smolíková, L.: Principles of soil development in the Quaternary, DEUQUA Spec. Pub., 3, 111-123, https://doi.org/10.5194/deuquasp-3-111-2021, 2021.

Special issue statement. This article is part of a special issue published on the occasion of the 70th anniversary of $E \& G$ Quaternary Science Journal (EGQSJ). The special issue celebrates the journal's notable contribution to Quaternary research by revisiting selected milestone articles published in the long history of EGQSJ. The German Quaternary Association (DEUQUA) presents translations of the originals and critical appraisals of their impact in tandem anniversary issues of DEUQUASP and EGQSJ, respectively.

Original article: https://doi.org/10.3285/eg.22.1.12

Tribute: https://doi.org/10.5194/egqsj-70-2472021

Translators: Clare Bamford, Christine Thiel and Henrik Rother

\section{Summary}

The objective of this paper is to describe the present-day status of Quaternary pedology in Central Europe and to focus attention on the prerequisites and possibilities for further progress of palaeopedology within the field of Quaternary research.

The methodical part offers a brief critical comparison of classical pedology with soil micromorphology and underlines the importance of using a micromorphological approach to investigate fossil soils. It is only through the joint study of fully developed system of soils based on a broad knowledge of natural science, with soil micromorphology and sedimentology, that the soils can be used most effectively in Quaternary research.

In the chapter dealing with the position of soils in the Quaternary climatic-sedimentary cycle, individual phases of the main soil formation periods are described and principal laws deriving from them are postulated.

The principles of the origin of various forms of soil conservation, the discernment of intact and disturbed strata etc. are the prime subject of the chapter devoted to the relation of soils to erosion and accumulation. The problems of vertical and horizontal zoning, of the facies of soil development an analogous of the present-day state, and of the facies conditioned by the substratum, are treated in the chapter on palaeopedological provinces.

The general palaeogeographical, palaeoclimatic, and stratigraphic importance of soils is most highlighted by the fact that they represent the valuable and widely distributed witnesses of former site conditions.

Based on the presented conclusions the vital importance of soils for understanding the more recent geological past is documented. If the phenomena of soil development are studied in detail, and results of these studies are then connected to information obtained from other scientific branches, pedology will become one of the principal investigative methods within the field of Quaternary research and will broaden the base of the natural sciences.

\section{Introduction}

From the point of view of Quaternary research, soil formations are of outstanding importance. They not only represent 
clear stratigraphic horizons, but also indicators which characterise certain climatic conditions. Accordingly, pedology and palaeopedology play an important role in Quaternary geology.

The utilisation of pedological results for Quaternary geological purposes is quite diverse, but it has not yet been possible to make full use of them, since the theoretical basis has remained inadequate until recently. Many Quaternary researchers are concerned with soil formation, who often have no in-depth pedological knowledge, which often results in incorrect and sometimes contradictory interpretations that make it very difficult to recognise the laws of soil formation processes in the Quaternary.

In order to eliminate such misconceptions, the following criteria must be taken into account for palaeopedological investigations:

1. Use of a fully developed systematic of modern soils (Kubiëna, 1953; Mückenhausen, 1962), which includes all soil types across all stages of development and allows for a detailed classification. The systems used in agricultural and forestry soil science practice usually cannot offer this.

2. Consideration of the mutual relationships between soil formation and geological processes.

3. The position of soils within the overall geological and biological context.

4. Application of a methodology, which is capable of recording such characteristics and on which Quaternary soil science can be based.

It is clear from the above that in many cases palaeopedological studies are confronted with exceptionally complicated problems. It is therefore no surprise that especially in older writings rather one-sided points of view can be found. The descriptions of the soils are often very simplified; sometimes using only vernacular terms, e.g., "Tabakzone", "Laimenzone", "limon fendillé" etc. (cf. Lautridou, 1969). Essential characteristics are frequently not recognised or ignored (e.g., different types of brown-coloured soils are not distinguished), while others are overemphasised (e.g., the strikingly dark colour of the chernozems). In other cases, secondary soil derivatives are confused with autochthonous soils, etc. For these reasons, it is hardly possible to critically evaluate the descriptions in many older writings.

My essay therefore aims to discuss the current state of Quaternary soil research in Central Europe, to draw attention to the necessary prerequisites and to appreciate the possibilities available to palaeopedology today.

\section{Methodological requirements}

A soil investigation is not to be carried out in isolation, it always belongs into a framework of a wider Quaternary geological investigations.

\subsection{The terrain investigation}

For each soil formation, its bedding features and development across the entire outcrop as well as its relationship to the relief must be taken into full account. Only in this way it is possible, for example, to recognise secondary imprints and disturbances and to delimit those sections in which soil derivatives have accumulated. Spatial tracing of the soil horizons also facilitates the correct evaluation of polygenetic soil formations, for example, in this view one can recognise the relationship of relief-related soil complexes and their corresponding polygenetic soil formations. Additionally, stratigraphic relationships of soils, their derivatives and formations of logically developed soil complexes, must be considered in detail. Finally, and if present, a possible fossil content or trace fossils in the soil (burrowing and worm passages, root tracts, etc.) should be carefully recorded.

\subsection{The laboratory tests}

Sampling should be based on results of earlier profile investigations. If a laboratory investigation is to be successful it must capture the overall picture of the soil as well as all traces of the various soil forming processes that have influenced the soil in different, i.e., past phases of development. Older methods of physical and chemical soil investigations have shown to be far too analytical in this respect. Results that refer only to individual, often very specific characteristics, and a synthesis based solely on such individual characteristics, are of less value than an investigation that captures the entire picture of soil development including the individual stages of soil formation in relation to the specific site conditions. Soil formations should be recorded, even if they only survive as remnants and are mixed in with fragments of other soil formations. The choice of analytical methods must correspond to the character of the individual object under investigation. In any case, soil micromorphology remains indispensable for capturing the overall picture of the soil.

It should also be noted that a complete sequence of fossil soil formations in the Quaternary sedimentary complexes is practically nowhere preserved. The only exceptions are those found in loess series of arid regions, which not only offer the most complete picture of the cyclic soil development but can also provide an approximate record of the entire time sequence. Loess is to be regarded as the ideal starting material, since it shows a very uniform formation over large areas and in different periods of time, not to mention that as a sediment cover, it preserves past soil formations in an excellent manner. As a substrate, loess reacts very sensitively to all changes 
in climate and vegetation, preserving features even of slight fluctuations and weakly developed soils (Kubiëna, 1956a).

Thus, the study of fossil soils preserved in loess offers the following advantages:

1. Possibility of comparing different soils from a relatively uniform substrate.

2. The soils are present in entire complexes, so that different soil types and varieties can be studied at one point.

\section{Position of soils within the climate-induced} sedimentation cycles of the Quaternary period

Quaternary sediments, soils and erosion levels form sequences that are cyclically repeated based on periodic climatic fluctuations. This change, on which most systems of Quaternary stratigraphy are based to a greater or lesser extent, is called the climate-induced sedimentation cycle. Soils play an important role in this process, both in terms of stratigraphy and site history, since the environmental conditions during certain periods can be reconstructed on the basis of soil formations (Bronger, 1966, 1969; Fedoroff, 1969). These relationships are complex as first order development cycles are often subdivided into second order sub-cycles which are less complex and less pronounced (cf. Kukla, 1961a).

The complete picture of cyclic development is provided by the loess series of the dry landscapes of Central Europe, in which almost the entire time sequence is represented by sediment and soil formations. In comparison, other sedimentary series are only partly developed, both in terms of their distribution in space and the individual time periods which they represent (cf. e.g., the inland water limestones, river terraces or cave fillings). From the attached overview Table 1, which shows the sedimentation and soil formation cycle of the loess series across Central European dry landscapes, it is evident that from a palaeopedological point of view phases 2 and 3 play the main role (Kukla, 1961a; Zagwijn and Paepe, 1968). They, as well as the other phases, have recently been described in more detail in another context (Smolíková, 1972); for the sake of brevity, reference must be made to this publication. Table 1 can only give a very brief overview of the complicated sedimentation and soil-forming processes.

It should be pointed out once again that practically all fossil soils of the loess series show clear characteristics of polygenesis, which are most evident in the interglacial soils (see Fig. 1) and may be related to the course of the climatic cycle. In most soil formations, the following successive stages of development can be distinguished:

1. Loess raw soil $\rightarrow$ initial stages corresponding to Pararendsina or "arctic" brown earths.

2. Decalcification and exposure of the initial brown loam (para-brown earth to brown loam under forest in the humid climate of the high interglacials).

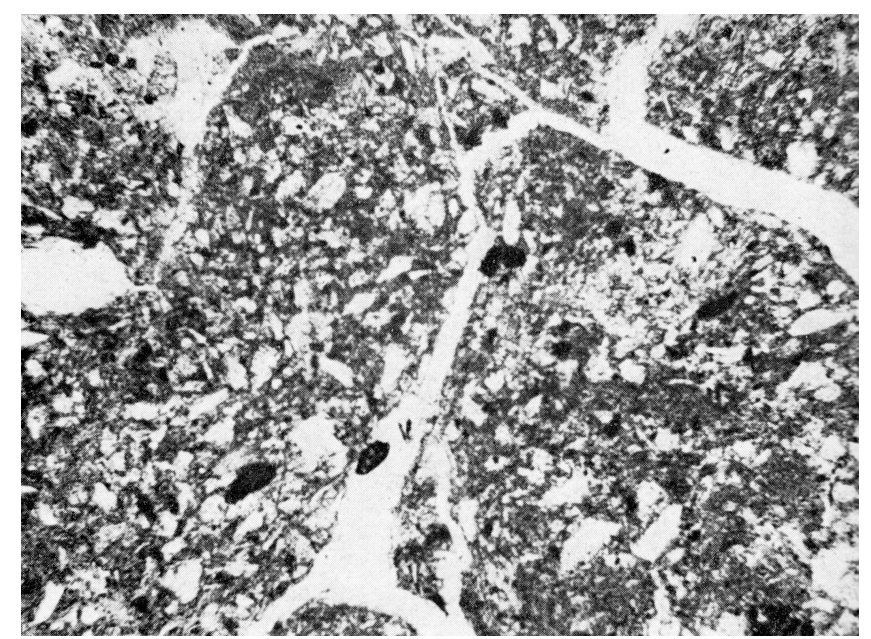

Figure 1. Pseudo-chernozem developed from a para-brown earth, the substrate of which is dominated by brown loam. - Lower polygenetic soil of PK VII ("Waal interglacial"), Červený kopec near Brno. Magnification approx. $80 \times$.

3. Granulation to humification (dehydration and moderate temperature reduction).

4. Moderate pseudo-gleyification (fading interglacial periods).

5. New sedimentation and formation of humic soils of the Chernozem series (increasing continentality at the beginning of the glacial period).

6. Weak pseudo-gleyification due to short-term humid fluctuation.

7. Mechanical disturbances and secondary calcareous enrichment due to a new loessification phase (high glacial climate). The sequence of these processes, which can only be fully recorded by micromorphological methods, substantially contributes to a better understanding of past climatic cycles and associated soil processes (Smolíková, 1968a, b).

\section{Relationship of soils and erosional processes}

From a palaeopedological point of view, the relief forms a decisive factor in the relationship between soil formation and processes of erosion or sedimentation. There is an absolute dependency of soil formation on terrain morphology. Two main cases can be distinguished:

1. Stable layers

2. Layers influenced by (a) erosion, (b) sedimentation

1. In stable layers, soil formation takes place in an undisturbed fashion and can reach the climax stage. 
Table 1. Sedimentation and soil development cycles in loess.

\begin{tabular}{|c|c|c|c|}
\hline & Phase & Sedimentation & Soil formation \\
\hline \multirow{7}{*}{ 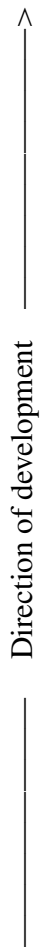 } & 6 & $\begin{array}{l}\text { Loess formation - other sedimentation or } \\
\text { soil formation processes very limited }\end{array}$ & $\begin{array}{l}\text { Loess raw soil - loessification } \\
\text { (oblessovanie, loessification) }\end{array}$ \\
\hline & 5 & $\begin{array}{l}\text { Alluvial sedimentation, which rhythmically transitions } \\
\text { gradually increasing aeolian (loess) sedimentation, } \\
\text { sometimes interrupted by solifluction. } \\
\text { (loamy sands ["Lehmbröckelsande"]) } \\
\text { Intensive accumulation of humic soil sediments }\end{array}$ & $\begin{array}{l}\text { Gradual transition to loess; } \\
\text { formation of weakly developed } \\
\text { soils of the Chernozem series } \\
\text { in shorter resting periods. }\end{array}$ \\
\hline & 4 & Short-term aeolian sedimentation ("marker") & $\begin{array}{l}\text { Interruption of soil formation; } \\
\text { decay of worm activity }\end{array}$ \\
\hline & 3 & $\begin{array}{l}\text { Moderate sedimentation (mainly slope sedimentation, } \\
\text { only rarely some loess), multiple phase change from } \\
\text { calm sections and stronger slope sedimentation. }\end{array}$ & $\begin{array}{l}\text { Chernozems under grass steppe (dry } \\
\text { and relatively cool inland climate); } \\
\text { periodic loessification in cold } \\
\text { intermediate phases. }\end{array}$ \\
\hline & 2 & $\begin{array}{l}\text { Sedimentation and erosion } \\
\text { quiescence - intense weathering }\end{array}$ & $\begin{array}{l}\text { Brown soil formations of para-brown earth type; } \\
\text { peak and late phase of the interglacials - dense } \\
\text { vegetation cover - dense forests }\end{array}$ \\
\hline & 1 & $\begin{array}{l}\text { Moderate redistribution of the loess, } \\
\text { mostly through slope washout }\end{array}$ & $\begin{array}{l}\text { Initial stages of soil formation, predominantly } \\
\text { Chernozems - rapid warming and } \\
\text { moisture increase }\end{array}$ \\
\hline & 6 & $\begin{array}{l}\text { Loess formation - aeolian dust accumulation; } \\
\text { other sedimentation and erosion processes } \\
\text { strongly inhibited }\end{array}$ & $\begin{array}{l}\text { Raw soils under cold-arid inland climate } \\
\text { (siallitic-carbonate weathering - loessification) }\end{array}$ \\
\hline
\end{tabular}

2. Layers exposed to erosion have either weakly developed soils (e.g., on steeper slopes) or soil remnants where one or more horizons are missing due to erosion.

Soils whose formation was inhibited by sedimentation are usually bound to depressions, dips or slope footings.

Within each climate-induced cycle, a systematic change of layers takes place, which repeats itself rhythmically:

1. The interglacial periods are always characterised by a substantial expansion of the stable layers.

2. The glacial periods show the maximum expansion of the disturbed layers.

These changes are decisive for the periods of undisturbed soil development. Only a few remain permanently undisturbed, which allows the preservation of old relict soils that always show strong polygenetic characteristics. In the remaining areas, i.e., in most of Central Europe, a gradation of soil formation can be followed, which usually corresponds to the development of the local relief. This often is controlled by shifts in the base level of erosion, the erosive activity of the water as well as surface erosion. The individual stages of this development are best expressed in the area of the river terraces, which often also allows a temporal classification of the processes in question. As an example, the following areas can be distinguished in Inner Bohemia: a. Area of \pm conserved Tertiary relief - essentially the terrain level above the highest Pleistocene terrace (Lysolaj Group in the Prague area, about $100 \mathrm{~m}$ above the present river).

b. Area of Quaternary erosion - i.e., at the level of the highest Pleistocene terrace and lower. Here, there is the possibility of a further gradation, i.e., a differentiation of the Early, Middle and Late Pleistocene relief. In places, a more detailed classification can be carried out, depending on the number of distinguishable terrace levels. Accordingly, other types of modelling, e.g., glacial, aeolian or solifluction relief, can be used depending on the conditions in the area studied (Picard, 1960).

Within the framework of individual landscapes, the soil types form systematic relief-related sequences known as catenas. The oldest soils are only bound to certain portions of these soil formation chains. As an example, we can consider nearflat areas which are divided by valleys: here the valley slopes and bottoms are affected by repeated erosion, so that the preservation of autochthonous old soil formations is hardly possible in these situations. On the other hand, the old soils are represented and preserved to varying degrees on flat sections of the surrounding plateau areas. The best examples of repeated and temporally graded soil developments are provided by large outcrops in the loess series with "telescopic" 


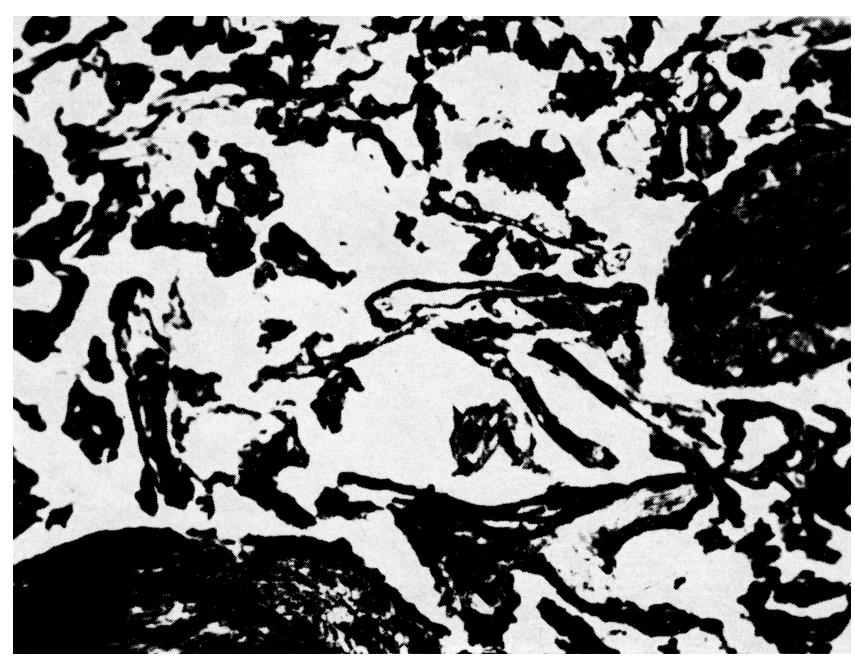

Figure 2. Immature humus forms within the A-horizon of a Protorensina of Holocene travertine. - Sivá Brada, Slovakia. Magnification approx. $90 \times$.

superposition in the slope end of river terrace stairs (Kukla, 1961b).

Even after the occurrence of limestone soils (Rendsina and Terrae calcis group), the minimum age of the relevant section of the terrain surface can be inferred, which also records the age of the erosion processes on which the relief under investigation is based. Such soil remains play an important role in the stratigraphic classification of terraces, travertines, slope debris breccias and other Quaternary formations or erosion processes, especially where other stratigraphic criteria are not available.

Based on the stage of development and the type of preservation of terrae calcis and rendsinas, the age of the karst surfaces in question can also be estimated, roughly according to the following scheme:

1. Relict terra-rossa soils always indicate Tertiary or Early Quaternary karst forms that were not destroyed by later erosion.

2. Relict terra fusca soils occur on flat surfaces that were formed during the Pleistocene (and which were not destroyed by later erosion).

3. Surfaces without terrae calcis, showing instead different developmental stages of rendsinas (Fig. 2), are very young and usually affected by Late Pleistocene erosion (Smolíková, 1961, 1963a, b; Smolíková and Ložek, 1962).

The differentiation of soil deposits based on age and degree of weathering may be possible not only based on their level of erosion but also based on overlying sediment covers or even lava sheets.

An example for the first scenario, areas featuring moraines of different glaciations, should be considered. Moraines of different ages bear soil formations that differ from each other both typologically and by the degree of their weathering. The same applies to loess covers, travertines and volcanic formations of different ages, e.g., in the basalt areas of Central Europe, the following soil series can be observed on basalt covers of different ages: red clay - brown earth - slope soil (cf. Kubiëna, 1956b).

As far as the Holocene is concerned, it is generally true that most of the areas, in which post-glacial soils developed, were originally formed during the Late Pleistocene, either due to erosion or Late Pleistocene deposition.

In the postglacial period, re-shaping of the relief by agriculture, as a human intervention, must also be considered.

It is clear from the above that the comparison of Holocene soil formations with older soils encounters obstacles, as the present day is characterised by rapid formation of soil residues and intense deposition of anthropogenic soil sediments (e.g., recent loamy sands; Kukla and Ložek, 1961). There is hardly any analogy for such conditions in the past and if there is one, it falls into periods with a different climate, i.e., the glacial periods. Accordingly, today's artificial state exhibits many phenomena that correspond to glacial conditions and not to interglacial conditions. This is due to human activity, which in the postglacial warm period replaced the disturbing influence of the glacial climate (loamy crumb sand formation, gravelling; Kukla and Ložek, 1961).

\section{Palaeopedological provinces}

The geographical distribution of soils and their changes within the framework of individual regions result in a colourful spectrum of soil facies formations. In climatically divergent areas, different soils are formed synchronously, while in different periods of time identical soils are formed in climatically corresponding regions. The soil zones of northern Eurasia can be cited as an example for this, albeit only as a coarse zoning concept. In contrast, much more complicated conditions can be observed in Central and Western Europe, which are characterised by many anomalies. These are due to the following factors:

a. Position in relation to the ocean (areas of decreasing oceanicity).

b. Position in relation to the mountains (rain shadow etc.).

If one follows the relationship of Central European soils to the classical soil zones of Eastern Europe, one must not forget that in many cases these are not identical but only similar soil formations. These differences are due to the more balanced, more oceanic climate of the West, which is mainly characterised by mild winters (Smolíková and Ložek, 1965).

From the above it can be seen that the Drno-podsol zone, corresponding to the mixed oak forest and separated from the 
southern so-called "cinnamon-coloured" forest soil zone ${ }^{1}$ of the Pontic mountain forests by the broad Chernozem area, gradually merges with the southern zone towards the west, while the Chernozem belt wedges out towards the west in an island shape. In Central Europe, both zones of brown soils already merge. Here, they form a colourful mosaic of gradual facies changes, which is due to an increasing oceanicity. This mixed area is also interspersed with Chernozem islands, which are bound to the driest districts. Accordingly, Central Europe features a whole range of brown soil formations, the differentiation of which is due not only to the varying climate but also to relief and substrate effects.

The Chernozem zone is bound to low-lying flat areas with steppe and forest-steppe stands. As already mentioned, the Ukrainian-Southern Russian Chernozem belt disintegrates towards the west into isolated islands, which lie in the Carpathian and Vienna basins, in the Moravian depressions as well as in Inner Bohemia, Thuringia and the Magdeburg Börde. Here, the true Chernozems are disappearing. Similar soil formations can be found even further west (Mückenhausen, 1962), but they are no longer typically developed and are confined to relatively small areas. They are all located in the old settlement landscapes.

The Central European (para)brown soil zone, including the soil formations of the heat-loving submeridional formations (downy oak stands with Cornelian cherry/Quercetum pubescentis with Cornus mas L.), whose northern border runs through Central Europe (Meusel, 1943). It mainly occupies the hilly areas and corresponds to the zone of brown and cinnamon soils in the south of the Soviet Union, where they are bound to the belt of beech stands and Pontic forests (south of the steppe zone).

A comparison of the Central European soil forming conditions with those of the Eastern European zones shows that in Central Europe areas of mixed deciduous forests, the steppes as well as the southern forests fade out, transitioning into a diverse mosaic depending on orographic and local climatic conditions. If one wants to apply the Eastern European zoning to Central Europe, one must make adjustments that take into account the differences mentioned, and only speak of corresponding, not identical sites and soils.

In addition to soil zonation in the horizontal sense (zone division), the corresponding vertical division (stage division) should also be noted, which appears at different altitude levels in the mountainous countries. The soil conditions in such areas are, however, much more complicated, as various relationships are found here which are the result of the change in substrate and exposition.

\footnotetext{
${ }^{1}$ In the case of the mixed deciduous forest soils ("počvy širokolistvennych lesov") summer temperatures play a decisive role (thus this zone stretches relatively far towards the north-east). For the cinnamon southern brown soils ("korycnevye pocvy") winter temperatures are critical (therefore this zone turns south towards the east).
}

In the geological past, too, there were climate zones to which certain soil zones corresponded. Over the course of time, shifts in these zones occurred in the sense of cyclical climate change, which resulted in corresponding changes in the soil climax at one and the same location. A reconstruction of soil zones and provinces in certain time phases is only possible where old soil formations could be preserved. In turn, the loess series offer favourable conditions, in which one can directly observe the changes to which the soils were subjected at one point. Here, one can also distinguish the soil provinces as well as the altitudinal levels. These problems have been dealt with in detail by Fink (1956), Kubiëna (1956a, 1964) and Brunnacker (1958).

In the zoning proposed by Kubiëna (1956a, 1964), a problematic position is occupied by the so-called Arctic soil province, which is regarded as an analogue of the glacial period conditions. It should be emphasised, however, that $\mathrm{Ku}-$ biëna (1956a, 1964) himself mentioned that loess does not occur in present Arctic areas. The term "arctic" must therefore be regarded in this case merely as an auxiliary term, since it only seeks to emphasise an analogy that refers to low temperatures. In reality, the past glacial conditions in Central Europe were quite different, as both floristic (Frenzel, 1964, 1968) and also faunistic findings (Ložek, 1964a, b) from the loess show. The same can also be deduced from the nature of the substrate itself. For the glacial period, a cold-arid inland climate was characteristic, the modern equivalent of which can most likely be found in the dry-cold areas of eastern Siberia, e.g., in Yakutia (Lukašev, 1961; Gerasimov, 1964). In view of the lack of newly processed modern comparative material, our glacial soil formations must be evaluated as a completely independent soil group that has no equivalent in present-day Europe.

The loess series, on which we primarily base these considerations, provides direct evidence for the changes that have taken place with regard to soil formation on the same substrate and site. At the same time, they allow a classification according to soil provinces and altitudinal levels (Table 2).

The boundaries between palaeopedological provinces of the individual interglacials and the present soil provinces only roughly coincide.

Deviations are evident from the comparison of recent and past interglacial soil formations of the loess series. In places where modern day Chernozems predominate (mostly more or less degraded), the last interglacial is usually represented by a typical para-brown earth (Inner Bohemia, South Moravia, e.g., in the classical outcrop of Dolni Vestonice). As already mentioned, the explanation of this difference can be sought in the deviating development during the postglacial, i.e., above all in the long-term influence of the peasant settlement of the Neolithics, which began already during the Atlantic period (5th millennium BC) representing an intervention exclusively characteristic of the postglacial period, which has no analogy in the older interglacial periods. 
Table 2. Scheme of soil formation in different climatic phases and soil zones of the Pleistocene.

\begin{tabular}{|c|c|c|c|c|}
\hline \multirow[t]{2}{*}{ Zone } & \multicolumn{4}{|c|}{ Phase } \\
\hline & High Glacial & Interglacial & $\begin{array}{l}\text { Interstadials of } \\
\text { the Early Glacial }\end{array}$ & $\begin{array}{l}\text { Warmer fluctuations } \\
\text { of the High Glacial }\end{array}$ \\
\hline Dry loess zone & $\begin{array}{l}\text { Loess (loessification } \\
=\text { oblëssovanie) }\end{array}$ & Para-brown earth & Chernozem & $\begin{array}{l}\text { weak brown soil formations } \\
\text { ("decalcification zone") }\end{array}$ \\
\hline Wet loess zone & $\begin{array}{l}\text { Loess (often partly } \\
\text { decalcified) } \\
\text { (loessification) }\end{array}$ & $\begin{array}{l}\text { Pseudo-gleyed } \\
\text { Para-brown earth }\end{array}$ & $\begin{array}{l}\text { weakly developed } \\
\text { Brown earth }\end{array}$ & $\begin{array}{l}\text { "Tundra gley soil" } \\
\text { (pseudo-gleyed } \\
\text { decalcification zone) }\end{array}$ \\
\hline Dust-loam zone & $\begin{array}{l}\text { Dust-loam ("loaming } \\
=\text { oglinenie") }\end{array}$ & $\begin{array}{l}\text { Pseudogley (strongly } \\
\text { developed) }\end{array}$ & $\begin{array}{l}\text { Pseudogley of weakly } \\
\text { formed Brown Earth }\end{array}$ & Pseudogley from wet soil \\
\hline $\begin{array}{l}\text { Slope sediments } \\
\text { zone }\end{array}$ & $\begin{array}{l}\text { Slope sediments with } \\
\text { coarse clastic component } \\
\text { (soil formation disturbed) }\end{array}$ & $\begin{array}{l}\text { Brown soils } \\
\text { Semi-podsols } \\
\text { etc. }\end{array}$ & $\begin{array}{l}\text { Weakly developed } \\
\text { soil formations } \\
\text { (rankers) }\end{array}$ & solifluction \\
\hline
\end{tabular}

As far as a comparison of the Late Pleistocene soils with older formations is concerned, we can so far say with certainty that a strong tendency to rubification prevailed in the Early Pleistocene interglacial periods and especially in the Late Tertiary - namely in the Pannonian region (Smolíková, 1967; Bronger, 1969). Tirsification is also present in this period, but humic steppe soils of the Chernozem type are almost unknown.

The approach of reconstructing palaeopedological provinces is practically identical to the reconstruction of vegetation zones. This can be based on numerous palaeobotanical findings available today (cf. Frenzel, 1964, 1968), which also offer further valuable criteria for the field of palaeopedology.

Apart from soils in loess, soils on carbonate or at least calcareous rocks can also be used for such purposes, and these are already fairly well known today.

Among the carbonate soils, the following are of highest importance:

a. Soils or soil sediments in the slope series of the karst landscapes.

b. Soil formations on the inland water limestones ("travertines").

As far as the soil formations in the area of carbonate rocks are concerned, the soils in the slope formations of the Mesozoic and Tertiary marl areas are to be mentioned first.

The relatively numerous occurrences of these soils, which are not only typologically identifiable (rendsinas and terrae calcis) but can also often be correlated based on their fossil record, make it possible to reconstruct the former distribution of individual soil types as well as their changes during the interglacial periods.

On the other hand, the fossil state of other soil types has remained practically unrecorded, which is especially true for various podsols and other silicate soils. Here, the reconstruction can only be based on analogies.

A reliable knowledge of the palaeopedological provinces or the former soil facies areas provides the necessary basis not only for a correct reconstruction of the former soil conditions but is also of fundamental importance for Quaternary stratigraphy.

\section{IV The palaeogeographical and palaeoclimatic significance of soils}

Although the fossil record must undoubtedly be regarded as the best indicator for former climatic and environmental conditions (Ložek, 1966), palaeosols can also play an excellent role in this respect. Compared to aerially widespread palaeosols, fossil finds are relatively rare and often only of local significance. On the other hand, past soils represent formations that can be traced over large areas, so that they provide suitable supports for the above-mentioned reconstructions.

For landscape and climate history purposes, the following two criteria are important in the case of palaeosols:

A. Pedological criteria

B. Correlation with fossil finds

\subsection{Pedological criteria}

In the case of old soils, the analogy with recent soil formations can be used for a climatic assessment, whereby the following prerequisites must be observed:

1. A perfect typological identification of the old soils with the corresponding recent soil types.

2. Reliable knowledge of the site conditions concerned. 
1. in the first case, one must rely on a precise determination and evaluation and avoid any rough generalisation, which is best possible on the basis of micromorphological investigations. It should also be emphasised that the soils studied must occur in autochthonous or at most par-autochthonous position.

2. each modern soil type corresponds to a specific ecotype, i.e., a natural site, which must form the starting point for any palaeopedological reconstruction.

In Quaternary studies, soils in loess in particular have received much attention. These soils hold the following advantages:

a. Very uniform substrate bound to one climatic zone,

b. Occurrence of soils from different palaeopedological provinces at one site,

c. Different typological affiliation of the soils at one site, which provides sufficient evidence for the climatic change of environmental factors.

The main pair of fossil loess soils can be cited as an example: the Chernozems (and Pararendsinas) have long been considered as evidence for a formerly warm-temperate climate (Pelíšek, 1949; Žebera, 1949), although their temperature range is much wider. They correspond to the steppe climate. According to the fauna, they fall into the phases of a dry climate, which has very large temperature fluctuations and therefore cannot simply be described as "warm", but at most as "summer-warm". It has been found that they are mainly characteristic of warmer fluctuations of the second order, i.e., of certain interstadials periods (Fig. 3). This observation, however, refers only to the Pleistocene Chernozems, as the Holocene types were formed under different conditions, to which the embedded mollusc fauna clearly testifies (Smolíková and Ložek, 1964). The Holocene Chernozems also formed under warm and at times rather humid climates, as the areas in question remained non-forested and steppe-like, thanks to human intervention. Accordingly, the Holocene Chernozem fauna differs from the fossil assemblages from the Pleistocene Chernozems by the presence of many warmth-requiring gastropod species, which were practically absent in the Pleistocene and whose arrival in Central Europe can only be attributed to the exceptional environmental conditions of the post-glacial period (so-called modern steppe species; Ložek, 1964a).

The illimerised soil formations, on the other hand, correspond to a long-term warm-wet climate and developed in forests. In the loess series they thus characterise the true warm periods, i.e., the interglacials (Smolíková and Ložek, 1965).

It should be emphasised that various weakly weathered brown soils (mostly decalcification zones with moderate oxidation and pseudo-gleyification) must be sharply distin-

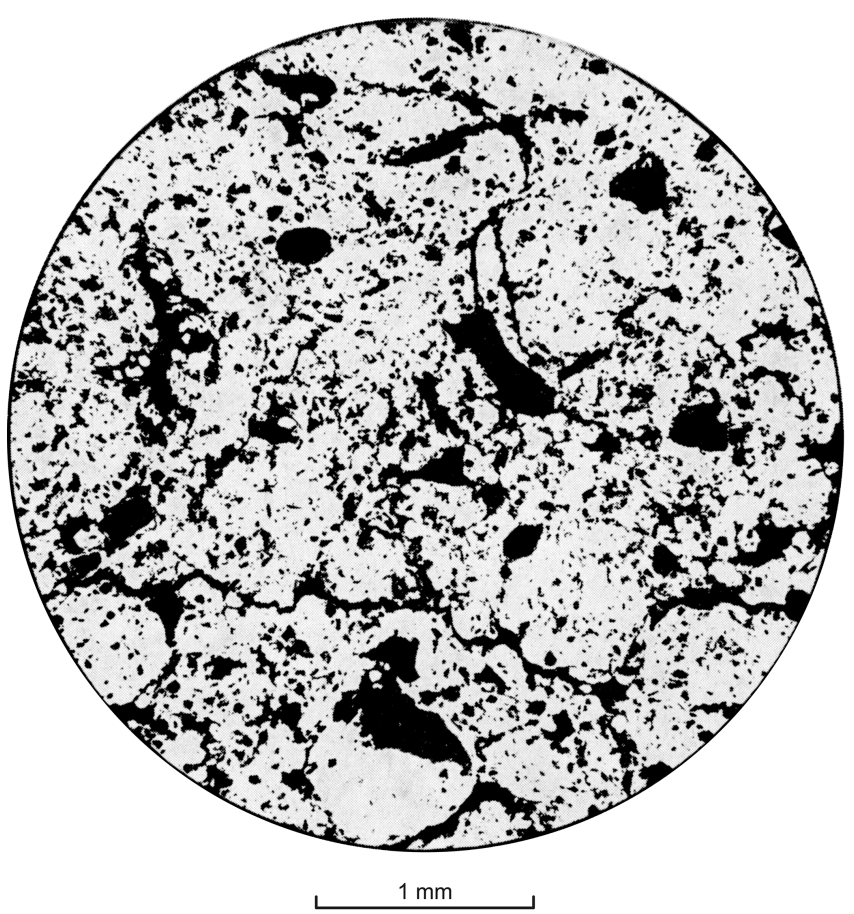

Figure 3. Characteristic sponge structure of a typical Chernozem. A-horizon of the lower soil formation of PK II ("W 1/2") in Modfice near Brno. Magnification approx. $100 \times$.

guished from the strongly weathered illimerised soils ${ }^{2}$. They correspond to warmer oscillations during pleniglacial periods and are usually compared with soil formations of the tundra ${ }^{3}$ ("arctic brown soils, initial pseudo-gleyification" etc.).

The terrae calcis soils are of similar importance. While the terra fusca indicates a climate similar to the presentday, which, however, must have a long-term effect (often polycyclic soil formations!), the terra rossa always represents evidence for a warmer, alternately humid climate of sub-Mediterranean character. In the Central European Pleistocene, terra rossa is so far only known from the oldest interglacial periods, when fauna and flora with many southern elements were still present in Central Europe (cf. Kretzoi, 1956).

Accordingly, other soil types can also be evaluated, which, however, in contrast to the loess and carbonate soils, are only rarely preserved.

\section{Correlation with fossil finds}

Two groups of fossils are important for the correlation of palaeontological finds with the fossil soil formations:

\section{Plant remains}

\footnotetext{
${ }^{2}$ Which, unfortunately, was not always the case, so that many older descriptions do not allow a more precise evaluation!

${ }^{3}$ The same can be said about the term "tundra" in this context as mentioned about the term "arctic".
} 


\section{Conchylia}

1. The plant remains are mostly represented in the soils in the form of pollen. Although these are preserved in large quantities only in a few favourable cases, the pollen analyses carried out so far offer such good results (Frenzel, 1964, 1968) that they can be used to reconstruct an overall picture of the adjacent landscape.

In addition, the palaeosols often contain charcoal and sometimes also fruits, especially of Celtis (Middle Pleistocene soil formations of the Inner Bohemian loess series, terra rossa sediments in karst cavities). Much more favourable, however, are the marsh soils, in which various macro-remains, namely the seeds, are preserved.

In addition, the plant opals (Werner, 1960) and other new formations, such as various types of root concretions, should be mentioned.

2. The mollusc shells, however, can only be preserved in calcareous materials, so that they can only be found in primarily calcareous soils, e.g., carbonate Chernozems and Rendsinas. The conchylia were secondarily introduced from the surface into deeper soil horizons by the activity of soil dwellers (small mammals, worms) after the animals died. Their fossilisation is thus directly linked to the biological perstruction of the A horizon.

Conchylia are on average much rarer than pollen. For palaeopedological purposes, however, they are of the highest value, as they allow in situ reconstruction of environmental conditions (Ložek, 1964a, 1969).

In addition to the conchyliferous autochthonous and parautochthonous soil formations, molluscs are also abundant in calcareous soil sediments, which offers favourable possibilities especially where rapid sedimentation of the soil material took place, revealing the individual stages of soil development. These are mainly soil sediments within slope deposits and cave fillings of the karst areas (Fig. 4), i.e., in areas without abundant molluscs, but they also offer favourable conditions for the preservation of ancient soil formations, which, in these settings, can often be correlated to vertebrate finds (Fig. 5).

Very characteristic are terra rossa sediments in vertical karst cavities, fissures and vents, which in many places contain Early Pleistocene bones and sometimes conchylia (Kretzoi, 1956; Fejfar, 1961; Dehm, 1961; Ložek and Skřivánek, 1966).

From the point of view of soil zoology, it is remarkable that, on the basis of the micromorphology, fossil biological activity can be detected in practically all loess soils. It was found, for example, that the proportion of small cavities due to the action of the edaphone varies between $20 \%-85 \%$. The stability of such traces presumably depends on their particular chemical and physical properties, which the biologically unaffected soil material apparently lacks. Surprising is the evidence of numerous traces of soil animals even in the oldest Pleistocene soil formations (Smolíková, 1967). These

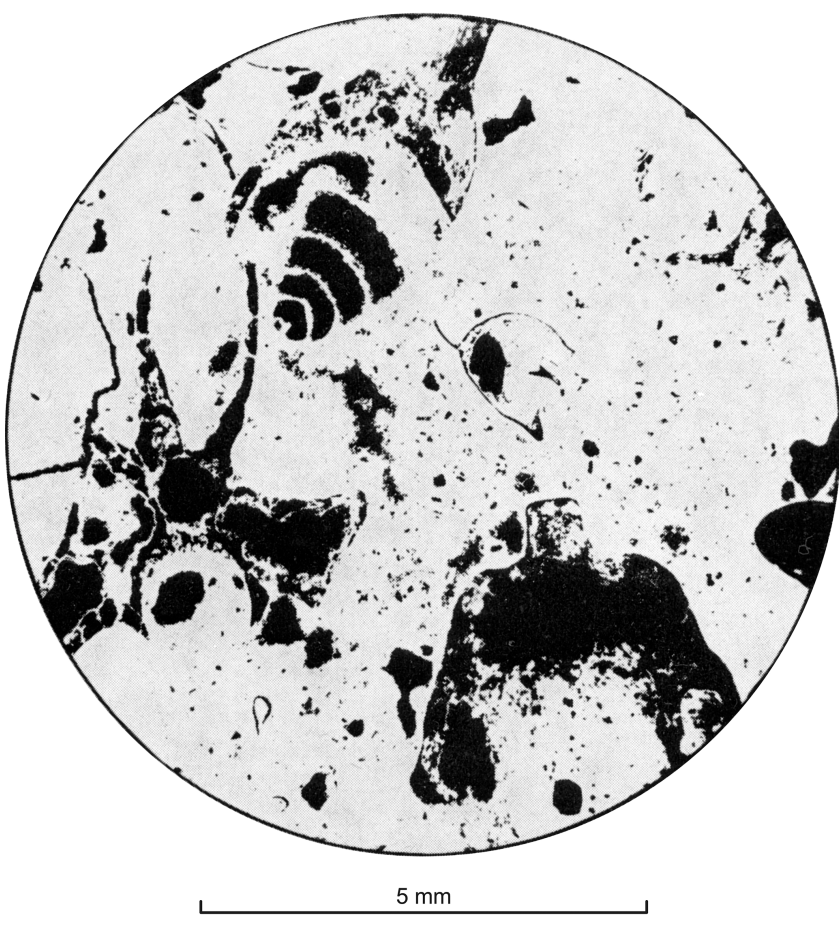

Figure 4. Snail shells and snake vertebrae in consolidated terra rossa sediments of Old Pleistocene age. Chalmová, central Slovakia.

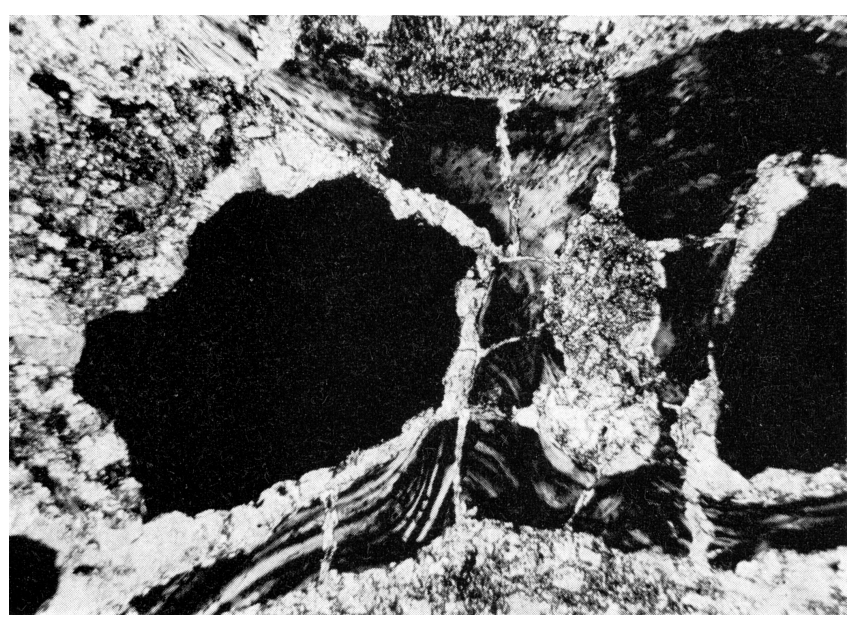

Figure 5. Snake vertebrae in sediments of an allitic terra rossa (probably Neogene age). Chalmová, central Slovakia. - Crosspolarised light. Magnification approx. $90 \times$.

are mostly excrements (Zachariae, 1967). In any case, much more attention should be given to these phenomena than has been the case so far, so that in future they can be more fully exploited for palaeopedological and Quaternary geological purposes.

In the case of soil sediments, however, it should be noted that their evaluation in correlation to palaeontological finds 
must be carried out with appropriate caution, for the following reasons:

1. The autochthonous and allochthonous fossil components must by all means be kept apart. Autochthonous fossil remains are those which have already been fossilised in the material of the original soil and thus characterise the former soil. However, such fossils can only occur in sediments of primarily calcareous soils. In strongly weathered, decalcified soil formations there are no faunal remains, so that their sediments can only carry fossils that were embedded when the soil sediment was deposited ${ }^{4}$ and are therefore allochthonous (Fig. 6).

2. The retardation, i.e., the time separating the deposition of the soil sediment from the formation of the original soil, can be of different lengths. Here, detailed stratigraphic methods of investigation must be used. As an example, terra rossa sediments in karst cavities can be cited, which according to the embedded fauna were undoubtedly deposited during the glacial periods (cf. point 1).

In such cases, one should always rely on a larger number of findings, since only on the basis of a statistical comparison can the true relationships be distinguished from possible anomalies. For example, the Early Pleistocene karst faunas are practically without exception restricted to soil sediments. If faunas common for the warm phases are present, they are usually embedded in terra rossa sediments - even where no terra rossa soils are present today or in the Late Pleistocene. From this it can be concluded that terra rossa was characteristic of the Early Pleistocene interglacial periods. In general, the fossil content indicates that the weak soil formations of phase 1 (cf. Table 1) correspond to light-coloured, strongly calcareous, often sintered sediments overlain by brown to red clayey layers (terra rossa sediments in the Early Pleistocene); these are characteristic of the high interglacials. The uppermost members of such series are mostly dark humic loams with debris, which are to be regarded as equivalent of the early glacial humus soils (this applies to the Cromer interglacial as well as to the Eemian or post-glacial).

Only a correct application of the knowledge of recent soils as well as the correlation with the fossil content enables full exploitation of the fossil soils (e.g., in the area of the loess series the differentiation of steppe, cold steppe, taiga and mixed deciduous forest soils), on which extensive reconstructions of landscape history can be based (e.g., the zoning in the early glacial period etc.; cf. Smolíková and Ložek, 1965).

\footnotetext{
${ }^{4}$ The terms autochthonous and allochthonous are used here in a palaeopedological sense, which deviates significantly from the way it is used in palaeontology (cf. Ložek, 1964a).
}

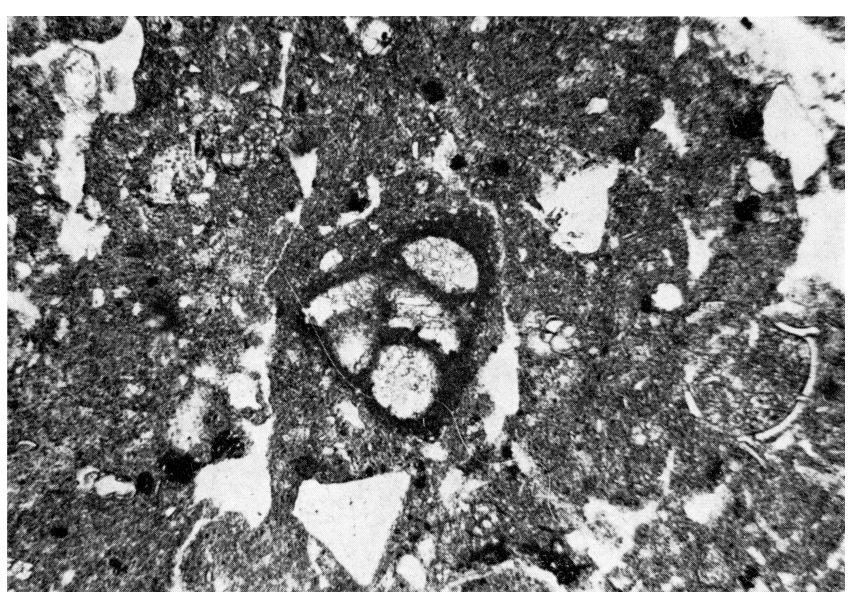

Figure 6. Cretaceous foraminifera as an allochthonous component in brown loamy relict soil of basaltic fine debris. - Litoměřice (Leitmeritz) III, Bohemian Central Uplands. Microphotos L. Smolíková.

\section{V Stratigraphic significance of the soils}

The stratigraphic significance of soil formations also results from the relationship between soils and climate, since most Quaternary geological systems are accompanied by climatic change. In stratigraphic research, soils are used in two ways:

1. As macroscopically distinctive horizons within terrestrial depositional sequences. In certain sedimentary complexes, e.g., in the loess series, palaeosols represent the only supporting points that enable the stratigraphic differentiation of individual loess layers. In this respect, soil complexes play an important role, as they represent the most significant pedostratigraphic units. They are often stratotypes that show a strict formation and on which regional parallelisation can be based (e.g., Stillfrieder Komplex; Fink, 1954, 1956).

When using the stratigraphic application of soil complexes, the following requirements must be met:

a. Precise topographic delineation of certain soil sequences evaluated in detail typologically,

b. Separation of the individual regions and their mutual correlation,

c. All conclusions must be based only on fully formed soil complexes (imperfect soil sequences, erosion residues, etc. must be excluded).

2. As indicators of the intensity of individual thermal fluctuations. As clear stratigraphic horizons, the soils are also of great importance from the point of view of chronology. Fully formed fossil para-brown soil, for example, always correspond to an interglacial, while Chernozems or Rendsinas can only correspond to minor fluctuations (interstadials). If a para-brown soil occurs in 
a loess profile that otherwise does not offer any stratigraphic criteria, one can conclude that the para-brown soil corresponds to the last interglacial or an older interglacial; younger phases, however, are excluded. A more detailed classification is already possible today on the basis of micromorphological examination.

The situation is similar in the case of terrae calcis soils and plastosols. It has been established that the allitic terra rossa in Central Europe correspond to the Late Tertiary, while the siallitic terra rossa and some transitional forms still developed in the oldest Pleistocene interglacial period. A fully formed terra fusca is one of the typical products of the interglacials, but is completely absent from the interstadials, while only imperfectly developed forms emerge in the postglacial period because the available formation period is too short (Smolíková and Ložek, 1962).

The basalts also offer a corresponding picture of soil development. While the present basalt soils typologically correspond to slope soils and eutrophic brown earths, the Early Pleistocene and Late Tertiary soil formations of basalt reach the red clay stage (Kubiëna, 1956b).

Even though the soils only allow rough stratigraphic estimates, they nevertheless provide significant clues, while they are clearly visible in the field, can easily be examined and occur over large areas.

In view of this, there have been numerous attempts to establish approximate stratigraphic systems on the basis of soils. This approach, often based exclusively on features such as typical soil colourations, have so far mainly been tested in the Mediterranean area (e.g., southern France, Alimen, 1955; Morocco, Klinge, 1958). Similar results can also be expected from soil investigations of travertines of different ages (Smolíková and Ložek, 1962), in slope deposition sequences, karst cavities fillings (Kretzoi, 1956; Smolíková, 1963b) and in thick loess series comprising many depositional cycles (Liu and Chang, 1964).

However, at present these methods are still only in the early stages of development. A prerequisite for their successful application is a modern and precise descriptive recording of the individual soil types, because older soil genetic systems allow only for rough generalisations so that they cannot meet the requirements of current stratigraphic geology.

\section{Conclusions}

The problem of Quaternary soils can only be solved on the basis of a scientific system that considers current soil formations, taking into account pedological conditions of all natural soil environments undisturbed by man.

Basically, soil development during the Quaternary is best characterised as a complicated polygenesis. The common, largely analytical methods applied in soil science are not yet capable of capturing the overall picture nor the individual development stages of soil formation. However, the newly de- veloped soil micromorphology provides these possibilities. However, the introduction of these methods into Quaternary research was only recent, so that the available set of information is still largely based on the results of analytical methods and field observations. In view of these recent developments, so far only a fraction of the existing information has been critically re-evaluated.

The correlation of soils with climatically induced sedimentation cycle of the Quaternary yields clear principles of soil development that correspond to individual phases of the cycle.

The relationship of soils to erosion and sedimentation shows that modern soils are usually difficult to compare with ancient soils, since the present is characterised by a rapid formation of soil residues and at the same time an intensive accumulation of soil sediments. These anthropogenic conditions are more reminiscent of the glacial periods than of the quiescent interglacials. The disruptive influence of the glacial climate is replaced in the post-glacial period by human activity (deforestation and agriculture).

Based on the reconstruction of the palaeopedological provinces as well as the soil facies in general, soil forming conditions within former climate zones can be traced over the course of the recorded climate change. A determination of soil zones and provinces for different phases of the climate-induced sedimentation cycle, however, is only possible where the past soils are preserved. In a rough framework, the reconstruction of palaeopedological provinces corresponds to the reconstruction of vegetation zones.

Any assessment of palaeosols with regard to reconstructions of landscape and climate histories must be based, firstly, on pedological criteria, i.e., on the exact typological identification of past soil formations and secondly, on finding a relevant modern soil environments that closely corresponds to the former site conditions. In addition, any reconstruction must take into account fossil finds embedded in the soil formations.

Palaeosols also represent excellent marker horizons in terrestrial depositional sequences, carrying information on the intensity and length of the relevant climatic fluctuations. They are therefore of primary importance for Quaternary stratigraphy and are rightly called pedostratigraphic zones.

Review statement. This paper was edited by Christine Thiel.

\section{References}

Alimen, H.: Colorimétrie de sédiments quaternaires et paléoclimats. Premiers résultats, B. Soc. Géol. Fr., 4, 609-619, 1955.

Bronger, A.: Lösse, ihre Verbraunungszonen und fossile Böden, Ein Beitrag zur Stratigraphie des oberen Pleistozäns in Südbaden, Schriften des Geographischen Instituts der Universität Kiel, Kiel, 114 pp., 1966. 
Bronger, A.: Zur Klimageschichte des Quartärs von Südbaden auf bodengeographischer Grundlage, Petermanns Geogr. Mitt., 113, 112-124, 1969.

Brunnacker, K.: Zur Parallelisierung des Jungpleistozäns in den Periglazialgebieten Bayerns und seiner östlichen Nachbarländer, Geologisches Jahrbuch, 76, 129-150, 1958.

Dehm, R.: Spaltenfüllungen als Lagerstätten fossiler Landwirbeltiere, Mitteilungen der Bayerischen Staatssammlung für Paläontologie und historische Geologie, 1, 57-72, 1961.

Fedoroff, N.: Les pedogeneses quaternaires en France, Lab. de geol.-pedol., de L'E.N.S.A. de Grignon, 1969.

Fejfar, O.: Die plio-pleistozänen Wirbeltierfaunen von Hajnáčka und Ivanovce/Slowakei/ČSR. I. Die Fundumstände und Stratigraphie, Neues Jahrbuch für Geologie und Paläontologie, 111, 257-273, 1961 .

Fink, J.: Die fossilen Böden im österreichischen Löß, Quartär, 6, 85-108, 1954.

Fink, J.: Zur Systematik fossiler und rezenter Lößböden in Österreich, Verhandlungen VI, Sixieme Congres Internat, de la Science du Sol, Paris, 585-592, 1956.

Franz, H.: Beiträge zur Kenntnis der Bodenentwicklung in NWSpanien auf Grund fossiler Böden, Annales de Edafologia y Agrobiologia, 26, 33-51, 1967.

Frenzel, B.: Zur Pollenanalyse von Lössen: Untersuchungen der Lößprofile von Oberfellabrunn und Stillfried (Niederösterreich), E\&G Quaternary Sci. J., 15, 5-39, https://doi.org/10.3285/eg.15.1.01, 1964.

Frenzel, B.: Grundzüge der pleistozänen Vegetationsgeschichte Nord-Eurasiens, Volume 1, Erdwissenschaftliche Forschung, F. Steiner, Wiesbaden, 326 pp., 1968.

Gerasimov, I. P.: Loess genesis and soil formation, Periglacial and Archaeological and Anthropological Sections and Symposium on Loess, Report of the VIth INQUA Congress, Warsaw, 1961, 4, 463-468, 1964.

Klinge, H.: Über spanische Terra rossa-Vorkommen und die Möglichkeiten ihrer zeitlichen Einordnung auf Grund bodengeographischer Studien, Zeitschrift für Pflanzenernährung, Düngung, Bodenkunde, 76, 223-231, https://doi.org/10.1002/jpln.19570760306, 1957.

Klinge, H.: Eine Stellungnahme zur Altersfrage von Terra-rossaVorkommen (unter besonderer Berücksichtigung der Iberischen Halbinsel, der Balearischen Inseln und Marokkos), Zeitschrift für Pflanzenernährung, Düngung, Bodenkunde, 81, 56-63, 1958.

Kretzoi, M.: Die altpleistozänen Wirbeltierfaunen des Villänyer Gebirges, Geologica Hungarica, 27, 1-264, 1956.

Kubiëna, W. L.: Bestimmungsbuch und Systematik der Böden Europas, Ferdinand Enke, Stuttgart, 392 pp., 1953.

Kubiena, W. L.: Zur Mikromorphologie, Systematik und Entwicklung der rezenten und fossilen Lößböden, E\&G Quaternary Sci. J., 7, 102-120, https://doi.org/10.3285/eg.07.1.10, 1956a.

Kubiëna, W. L.: Zur Methodik der Paläopedologie, Actes du IV Congrès international du quaternaire, Rome-Pise, AoûtSeptembre, 1953, 4, 297-305, 1956b.

Kubiëna, W. L.: Zur Mikromorphologie und Mikromorphogenese der Lößböden Neuseelands, in: Soil Micromorphology, edited by: Jongerius, A., Elsevier, Amsterdam, 219-235, 1964.

Kukla, J.: Quaternary Sedimentation Cycle, Survey of Czechoslovak Quaternary, Institut Geologiczny, 34, 145-154, 1961a.
Kukla, J.: Lithologische Leithorizonte der tschechoslowakischen Lößprofile, Věstník Ustředního Ústava Geologického, 36, 359372, 1961b.

Kukla, J. and Ložek, V.: Loesses and Related Deposits, Czwartorzed Europy Środkowej i Wschodniej, 34, 11-28, 1961.

Lautridou, J. P.: Commission de terminologie des limons, Mémoires de la Société géologique de France, Paris, 123-137, 1969.

Liu, T. and Chang, T.: The "Huangtu" (loess) of China, Report of the VIth INQUA Congress, Warsaw, 1961, 4, 503-524, 1964.

Ložek, V.: Quartärmollusken der Tschechoslowakei, Geologischer Zentralanstalt, Tschechoslowakische Akademie der Wissenschaften, Praha, vol. 31, 1964a.

Ložek, V.: Stratigraphische Bedeutung der Quartärmollusken, Report of the VIth INQUA Congress, Symposium on Loess, Warsaw, Lódž, 1961, 4, 525-549, 1964b.

Ložek, V.: Die quartäre Klimaentwicklung in der Tschechoslowakei, Quartär, 17, 1-19, 1966.

Ložek, V.: Über die malakozoologische Charakteristik der pleistozänen Warmzeiten mit besonderer Berücksichtigung des letzten Interglazials, Berichte der Deutschen Gesellschaft für Geologische Wissenschaften, 14, 439-469, 1969.

Ložek, V. and Skřivánek, F.: The Significance of Fissures and their Fills for Dating of Karst Processes, Československý kras, 17, 722, 1966.

Lukašev, K. I.: Problem lëssov v svete sovremennych predstavlenij, Izdatělstvo AN BSSR, Minsk, 1961.

Meusel, H.: Vergleichende Arealkunde, I, Bornträger, Berlin, 1943.

Mückenhausen, E.: Entstehung, Eigenschaften und Systematik der Böden der Bundesrepublik Deutschland, DLG-Verlag, Frankfurt am Main, 148 pp., 1962.

Pelíšek, J.: Příspěvek ke stratigrafii spraší svrateckého úvalu (A contribution to the stratigraphie of loess in the Svratka river valley [Czechoslovakia]), Práce Mor.-slez. Akad. Věd přír., Brno, 21, 11 pp., 1949.

Picard, K.: Zur Untergliederung der Saalevereisung im Westen Schleswig-Holsteins, Zeitschrift der Deutschen Geologischen Gesellschaft, 112, 316-325, https://doi.org/10.1127/zdgg/112/1960/316, 1960.

Rohdenburg, H.: Ein Beitrag zur Deutung des "Gefleckten Horizontes", E\&G Quaternary Sci. J., 15, 66-71, https://doi.org/10.3285/eg.15.1.05, 1964.

Ruske, R. and Wünsche, M.: Lösse und fossile Böden im mittleren Saale- und unteren Unstruttal, Geologie, 10, 9-29, 1961.

Smolíková, L.: Stratigraphical significance of Terrae Calcis soils, INQUA, Abstracts of Papers, PWN, 34-35, 1961.

Smolíková, L.: Stratigraphische Bedeutung der Terrae calcisBöden, Antropozoikum, 1, 101-126, 1963a.

Smolíková, L.: Räz vyskytu terrae calcis v krasovych oblastech Slovenska. (Different Forms of Occurence of Terrae Calcis in Karst Areas of Slovakia), Československý kras, 14, 93-100, $1963 b$.

Smolíková, L.: Výzkum kvartéru na listech B. Bystrica a Sl.'Lúpča (Listy M-34-111-C a M-34-111-D), Zpr. geol. Výzk., 276-277, 1964.

Smolíková, L.: Mikromorphologie der altpleistozänen Fossilböden von Červený kopec bei Brno (Brünn), Věstník ÚÚG, 42, 369373, 1967.

Smolíková, L.: Polygenese der fossilen Lößböden der Tschechoslowakei im Lichte mikromorphologischer Untersuchun- 
gen, Geoderma, 1, 315-324, https://doi.org/10.1016/00167061(67)90034-1, 1968a.

Smolíková, L.: Genese mladopleistocénních půd v Modřicích u Brna na základě půdní mikromorfologlie (Genese der jungpleistozänen Fossilböden von Modřice bei Brno auf Grund mikromorphologischer Untersuchungen), Časopis pro mineralogii a geologii, 13, 199-209, 1968b.

Smolíková, L.: Bedeutung der Paläoböden im Rahmen des quartären klimatischen Zyklus, Antropozoikum, 6, 57-76, 1972.

Smolíková, L. and Ložek, V.: Zur Altersfrage der mitteleuropäischen Terrae calcis, E\&G Quaternary Sci. J., 13, 157-177, https://doi.org/10.3285/eg.13.1.11, 1962.

Smolíková, L. and Ložek, V.: The Holocene Soil Complex of Litomefice, Antropozoikum, 2, 41-56, 1964.

Smolíková, L. and Ložek, V.: Stratigrafičeskoe i paleoklimatičeskoe značenie četvertičnych iskopaemych počv Srednej Evropy, Bjulletin Komm, po Iz. četv. Perioda, 33, 26-46, 1965.

Werner, J.: Gips-Ausblühungen an Bodenaufschlußwänden, Zeitschrift für Pflanzenernährung, Düngung, Bodenkunde, 47, 3-9, https://doi.org/10.1002/jpln.19620970103, 1960.
Zachariae, G.: Der Einsatz mikromorphologischer Methoden bei bodenzoologischen Arbeiten, Geoderma, 1, 175-195, https://doi.org/10.1016/0016-7061(67)90026-2, 1967.

Zagwijn, W. and Paepe, R.: Die Stratigraphie der weichselzeitlichen Ablagerungen der Niederlande und Belgiens, E\&G Quaternary Sci. J., 19, 129-146, https://doi.org/10.3285/eg.19.1.08, 1968.

Žebera, K.: K současnému výzkumu kvartéru v oblasti Českého masivu (A propos de l'exploration actuelle des terrains quaternaires dans le domaine du Massif Bohémien), Sbor. St. geol. Üst., 16, 731-781, 1949. 